\title{
Device Location During Observation
}

National Cancer Institute

\section{Source}

National Cancer Institute. Device Location During Observation. NCI Thesaurus. Code C69254.

Location of the automated observation device during an observation. 